\title{
PERBEDAAN PENGARUH METODE PEMBELAJARAN KOOPERATIF TIPE TSTS (TWO STAY TWO STRAY) DAN METODE CERAMAH TERHADAP HASIL BELAJAR PKn PADA SISWA KELAS $X$ SMA NEGERI 1 PABELAN KECAMATAN PABELAN KABUPATEN SEMARANG SEMESTER GANJIL TAHUN AJARAN 2012/2013
}

\author{
Prihartini \\ Alumni Progdi S1 PPKn FKIP Universitas Kristen Satya Wacana \\ Nani Mediatati \\ Progdi S1 PPKn FKIP Universitas Kristen Satya Wacana \\ nani.mediatati@staff.uksw.edu
}

\begin{abstract}
ABSTRAK
Penelitian ini bertujuan untuk mendeskripsikan ada tidaknya perbedaan pengaruh yang signifikan antara metode pembelajaran kooperatif tipe TSTS dan metode Ceramah terhadap hasil belajar PKn pada siswa kelas X SMA Negeri 1 Pabelan Kecamatan Pabelan Kabupaten Semarang semester ganjil tahun ajaran 2012/2013. Penelitian ini merupakan penelitian eksperimen, dengan desain penelitian Postest Only Control Design. Populasi dalam penelitian ini adalah siswa kelas X SMAN 1 Pabelan, yang terdiri dari lima kelas. Adapun sampel dalam penelitian ini kelas X-2 sebagai kelas eksperimen dan kelas X-1 sebagai kelas kontrol.Teknik yang digunakan dalam mengumpulkan data adalah tes. Hasil Uji validitas dan reliabilitas instrumen tes dari 45 soal yang diuji terdapat 37 soal yang valid dan 8 soal yang tidak valid sedangkan hasil uji reliabilitas sebesar 0,855. Teknik analisis data menggunakan uji Independent Samples T-test yang dilakukan dengan tahapan yaitu; Uji prasyarat analisis (Uji Normalitas dan Uji homogenitas) dan Uji hipotesis dengan bantuan program SPSS for window version 18. Hasil Uji normalitas berdasarkan uji Kolmorgorov-Smirnov menunjukkan bahwa distribusi nilai sampel pada kelas eksperimen dan kontrol berasal dari populasi yang normal.Pada taraf signifikansi kelas kontrol adalah 0,81, pada kelas eksperimen taraf signifikansinya 0,70 . Uji homogenitas dengan Levene Statistic pada kelas eksperimen dan kontrol taraf signifikansinya adalah 0,622 menunjukkan bahwa varians kelas eksperimen dan kontrol adalah homogen. Nilai rata-rata teshasil belajar pada kelas eksperimen $(80,24)$ dan kelas kontrol $(76,24)$ yang mempunyai selisih rata-rata 4 poin. Nilai rata-rata kelas eksperimen lebih tinggi dibandingkan dengan nilai rata-rata kelas kontrol. Hasil analisis uji hipotesis dengan uji Independent Sample T-Test menunjukkan bahwa dalam pengujian statistik uji $\mathrm{T}\left(\mathrm{T}_{\text {test }}\right)$, pada taraf signifikansi 5\%, df 40 , dan $\mathrm{T}_{\text {tabel }}=1,684$ diperoleh $\mathrm{T}_{\text {hitung }}=-2,131$ sehingga $-1,684<-2,131<1,684$. Hal ini menunjukkan $\mathrm{H}_{0}$ ditolak dan $\mathrm{H}_{1}$ diterima, yang berarti ada perbedaan pengaruh yang signifikan antarametode pembelajaran kooperatif tipe TSTS dan metode Ceramah terhadap hasil belajar siswa pada mata pelajaran PKn.
\end{abstract}

Kata Kunci:Two Stay Two Stray (TSTS), Ceramah, Hasil Belajar

\section{PENDAHULUAN}

Paradigma lama yang muncul dalam proses pembelajaran adalah guru memberikan pengetahuan kepada siswa dan siswa hanya menerima pengetahuan dari guru. Menurut Lie
(Made, 2011) dalam proses pembelajaran ini guru mengajar dengan menggunakan metode ceramah dan mengharapkan siswa duduk, diam, dengar, catat dan hafal. Hampir dalam segala keadaan metode ini dianggap cara yang paling baik bagi seorang pendidik untuk 
menyajikan secara lisan tentang informasi suatu mata pelajaran.

Penggunaan metode ceramah menurut Vianata (2012) menyebabkan partisipasi siswa rendah, kemajuan siswa kurang, perhatian dan minat siswa tidak dapat dipantau, sehingga menjadikan siswa tidak aktif. Ketidakaktifan siswa selama proses pembelajaran merupakan salah satu faktor yang dapat mengakibatkan siswa sulit memahami konsep suatu materi. Jika hal tersebut terjadi maka hasil belajar yang diperoleh kurang optimal sehingga dapat dikatakan tujuan pembelajaran tidak tercapai.

Paradigma baru menuntut peningkatan keikutsertaan peserta didik secara aktif dalam proses kegiatan belajar mengajar. Dengan aktifnya siswa diharapkan hasil pembelajaran dapat meningkat dan kegiatan pembelajaran lebih bermakna. Menurut Lie (Made, 2011) berdasarkan penelitian pembelajaran dengan rekan sebaya (peer teaching) melalui pembelajaran kooperatif ternyata lebih efektif dari pada pembelajaran oleh pengajar. Dengan demikian metode pembelajaran kooperatif dapat meningkatkan aktivitas siswa melalui kerjasama antar siswa sehingga informasi tidak berpusat pada guru.

Ada berbagai macam metode pembelajaran kooperatif salah satunya, yang akan dipakai dalam penelitian ini adalah metode pembelajaran kooperatif tipe TSTS (Two Stray Two Stay). Dalam pembelajaran kooperatif tipe TSTS peserta didik tidak hanya bekerja dalam individu namun di dalam kelompok dan antar kelompok lain dengan membagi informasi dan melihat pekerjaan dari kelompok lainnya.

Berdasarkan permasalahan tersebut maka dilakukan penelitian untuk mengetahui perbedaan pengaruh metode pembelajaran kooperatif tipe TSTS dan metode Ceramah terhadap hasil belajar siswa, khususnya pada mata pelajaran PKn pada siswa kelas X SMAN 1 Pabelan Kecamatan Pabelan, Kabupaten Semarang semester ganjil tahun ajaran 2012/2013.

\section{TINJAUAN PUSTAKA}

\section{Hasil Belajar}

Menurut Sudjana (2010) hasil belajar siswa pada hakikatnya adalah perubahan tingkah laku.Tingkah laku sebagai hasil belajar dalam pengertian luas mencakup aspek kognitif, afektif dan psikomotorik. Menurut Slameto (2010), faktor-faktor yang mempengaruhi hasil belajar dibedakan menjadi dua yaitu: faktor intern dan faktor ekstern. Faktor intern adalah faktor yang ada dalam diri individu yang sedang belajar, sedangkan faktor ekstern adalah faktor yang ada dari luar individu. Faktor-faktor intern terbagi tiga faktor yaitu: faktor jasmaniah, faktor psikologis, dan faktor kelelahan. Sedangkan faktor ektern terdapat tiga faktor yaitu: faktor keluarga, faktor sekolah, dan faktor masyarakat. Faktor keluarga meliputi cara orang tua mendidik, relasi antar anggota keluarga, suasana rumah tangga, keadaan ekonomi keluarga, pengertian orang tua dan latar belakang kebudayaan. Faktor sekolah, meliputi metode pembelajaran, kurikulum, relasi guru dengan siswa, relasi siswa dengan siswa, disiplin sekolah, alat pelajaran dan waktu sekolah, standar pelajaran, keadaan gedung, metode belajar, dan tugas rumah. Faktor masyarakat, meliputi kegiatan siswa dalam masyarakat, mass media, teman bergaul dan bentuk kehidupan masyarakat. Metode pembelajaran merupakan salah satu faktor yang mempengaruhi hasil belajar. Pemilihan metode pembelajaran yang akan digunakan oleh guru harus sesuai dengan kondisi pembelajaran baik tujuan pembelajaran dan karakteristik bidang studi (Made, 2011).

\section{Metode Ceramah}

Metode ceramah adalah suatu cara penyajian bahan ajar atau cara mengajar melalui penjelasan atau penuturan secara lisan oleh guru kepada peserta didik. Adapun langkah-langkah pembelajaran dengan metode 
ceramah yang harus diperhatikan guru menurut Widi Rahardja (2002) yaitu:

\section{Persiapan}

Pada tahap ini guru melakukan kegiatankegiatan antara lain: menata secara sistematis/mengorganisir bahan pelajaran yang akan disajikan, menentukan urut-urutan penyajian, agar bagi guru ataupun siswa dapat dengan memahami dan menguasai bahan pelajaran tersebut.

2. Awal ceramah

Hal ini sebagai pengantar/introduksi dimana guru membuka pelajaran dengan kegiatan-kegiatan antara lain menumbuhkan motivasi dan perhatian siswa mendorong rasa ingin tahu dengan pernyataan yang menantang/merangsang berpikir siswa dengan mengemukakan pokok-pokok isi/ materi pelajaran serta meningkatkan hubungan/pola interaksi guru dan siswa.

3. Pelaksanaan ceramah

Tahap ini merupakan kegiatan inti/kegiatan utama dimana guru menyajikan bahan pelajaran yang telah dipersiapkan pada siswa di kelas. Hal-hal yang harus diperhatikan guru adalah penggunaan kata-kata yang sederhana, gaya bicara/suara yang menarik, penjelasan singkat/jelas sehingga siswa akan lebih mudah dalam memahami materi pelajaran.

4. Akhir ceramah

Merupakan kegiatan akhir dari guru dalam menerapkan metode ceramah yaitu dengan membuat kesimpulan atau rangkuman secara garis besar dari isi pelajaran yang baru saja dijelaskan, dapat dilakukan oleh guru atau oleh siswa: a) Mengadakan evaluasi/postes, dan b) Mengemukakan materi yang akan datang/tugas berikutnya. Kelemahan metode ceramah antara lain: kegiatan lebih berpusat pada guru sehingga peserta didik pasif dan hanya menghasilkan ingatan jangka pendek pada siswa.

\section{Metode Pembelajaran Kooperatif TSTS}

Metode pembelajaran kooperatif TSTS, merupakan metode pembelajaran yang dikembangkan oleh Spancer Kagan pada 1992. Menurut Lie (2002) metode pembelajaran kooperatif TSTS memberi kesempatan kepada kelompok untuk membagikan hasil dan informasi dengan kelompok lain.

Adapun langkah-langkah pelaksanaan metode pembelajaran kooperatif tipe TSTS (Two Stay Two Stray) menurut Lie (Yusritawati, 2009, http://furahasekai.wordpress.com/2011/ 09/07/pembelajaran kooperatif tipe Two Stay Two Stray. Diakses pada tanggal 5 November 2012 jam 2:15pm) yaitu:

1. Guru membagi siswa dalam beberapa kelompok yang setiap kelompoknya terdiri dari empat siswa. Kelompok dibentuk harus merupakan kelompok yang heterogen, seperti pada pembelajaran kooperatif tipe Two Stay Two Stray yang bertujuan untuk memberikan kesempatan pada siswa untuk saling membelajarkan (Peer Tutoring).

2. Guru memberikan sub pokok bahasan pada tiap-tiap kelompok untuk dibahas bersamasama dengan anggota kelompoknya.

3. Siswa bekerjasama dalam kelompok beranggotakan empat orang. Hal ini bertujuan untuk memberikan kesempatan kepada siswa untuk dapat terlibat secara aktif dalam proses berpikir.

4. Setelah selesai, dua orang dari masingmasing kelompok meninggalkan kelompoknya untuk bertamu ke kelompok lain

5. Dua orang yang tinggal dalam kelompok bertugas membagikan hasil kerja dan informasi mereka ke tamu mereka.

6. Tamu mohon diri dan kembali ke kelompok mereka sendiri dan melaporkan hasil temuan mereka dari kelompok lain.

7. Kelompok mencocokkan dan membahas hasil-hasil kerja mereka.

8. Masing-masing kelompok mempresentasikan hasil kerja mereka. 
Keunggulan dari metode ini lebih beorientasi pada keaktifan siswa dan membantu meningkatkan minat dan prestasi belajar Susanti (Siti Aminah, 2009, http://psb-psma.org/content/ blog/pembelajaran kooperatif. Diakses tanggal 21 November 2011 jam 10.15 am). Penelitian yang dilakukan oleh Yusti Palupi Megasari (2011) tentang perbedaan prestasi belajar siswa yang diajar menggunakan metode ceramah dengan siswa yang diajar menggunakan metode kooperatif model Two Stay Two Stray pada mata pelajaran IPS bidang sejarah menunjukkan adanya perbedaan yang signifikan antara prestasi belajar siswa yang diajar menggunakan metode pembelajaran ceramah dengan siswa yang diajar dengan metode kooperatif model Two Stay Two Stray pada mata pelajaran IPS bidang Sejarah kelas VII SMP Negeri 3 Batu. Terbukti dari nilai Sig. $(0,004)<0,05$. dan thitung $(3,010)>$ tabel $(1,999)$ yang menyatakan ada perbedaan dari kedua kelompok tersebut. Rata-rata nilai gain score siswa kelas eksperimen $(31,5625)$ lebih tinggi daripada rata-rata nilai gain score siswa kelas kontrol $(25,0968)$.

\section{METODE}

Penelitian ini adalah penelitian eksperimen dengan rancangan penelitian "Postets Only Control Design”. Dalam rancangan ini terdapat dua kelompok yang masing-masing dipilih secara random (R). Kelompok pertama diberi perlakuan disebut kelompok eksperimen dan kelompok yang tidak diberi perlakuan disebut kelompok kontrol.

\begin{tabular}{|lcc|}
\hline $\mathbf{R}$ & $\mathbf{X}$ & $\mathbf{O}_{1}$ \\
$\mathbf{R}$ & & $\mathbf{O}_{2}$ \\
\hline
\end{tabular}

Keterangan :

$\mathrm{R}$ : Kelas eksperimen dan kelas kontrol

$\mathrm{X}$ : Perlakuan/treatment

$O_{1}$ : Hasil belajar kelas eksperimen yang diberi perlakuan dengan TSTS

$\mathrm{O}_{2}$ : Hasil belajar kelas kontrol yang menggunakan metode Ceramah
Populasi dalam penelitian ini adalah seluruh siswa kelas X SMAN 1 Pabelan, Kecamatan Pabelan, Kabupaten Semarang semester ganjil tahun ajaran 2012/2013, yang terdiri dari 5 (lima) kelas yang berjumlah 107 siswa. Dalam penelitian ini sampel yang digunakan adalah kelas X-2 sebagai kelas eksperimen yang berjumlah 21 siswa dan kelas X-1 sebagai kelas control. Sebagai kelas uji validitas X-3 berjumlah 20 siswa.

Teknik pengumpulan data dalam penelitian ini adalah teknik tes. Alat pengumpulan data dalam penelitian ini adalah butir-butir soal tes hasil belajar siswa pada mata pelajaran pendidikan kewarganegaraan dan instrumen soal berbentuk obyektif tertulis berupa pilihan ganda. Uji validitas yang digunakan dalam penelitian ini adalah validitas butir soal, berdasarkan hasil uji dengan menggunakan bantuan SPSS 18.0 di atas dapat dilihat dari 45 soal diuji terdapat 37 soal yang valid. Sedangkan hasil uji reliabilitas instrumen tes dengan menggunakan SPSS 18 diperoleh reliabilitas sebesar 0,855. Hal ini menunjukkan bahwa instumen test sudah valid dan reliabel.

Teknik statistik yang digunakan dalam penelitian ini adalah "statistik parametris". Analisis data menggunakan "Teknik analisis $\mathrm{T}_{\text {tes }}(\mathrm{uji})$ ", dengan uji prasyarat yaitu uji normalitas dan uji homogenitas.

\section{HASIL PENELITIAN DANPEMBAHASAN}

Hasil analisis data tes akhir atau postes antara kelas eksperimen dan kelas kontrol dapat dilihat sebagai berikut: Pada kelas eksperimen diperoleh rata-rata hasil belajar siswa 80,24, sedangkan pada kelas kontrol ratarata hasil belajar siswa adalah 76,24. Berdasarkan uji normalitas Kolmogorov-Smirnov pada taraf signifikansi 5 persen distribusi nilai sampel kelas eksperimen dan kontrol berasal dari populasi normal. Taraf signifikansi kelas kontrol 0,81>0,05 dan kelas eksperimen 0,70 $>0,05$. Uji normalitas pada tabel 1 berikut, 
Tabel 1. Hasil Uji Normalitas

Tests of Normality

\begin{tabular}{lllllll}
\hline & \multicolumn{3}{l}{ Kolmogorov - Smirnov $^{\text {a }}$} & \multicolumn{4}{c}{ Shapiro-Wilk } \\
& Statistic & Df & Sig. & Statistic & Df & Sig. \\
\hline Kontrol &, 178 & 21 &, 081 &, 881 & 21 &, 015 \\
Eksperimen &, 181 & 21 &, 070 &, 925 & 21 &, 108 \\
\hline
\end{tabular}

a. Lilliefors Significance Correction

Sumber: Hasil penelitian 2013

Berdasarkan hasil pengujian homogenitas dengan Levene Statistic pada kelas eksperimen dan kelas kontrol taraf signifikansinya adalah 0,622 . Hasil pengujian ini lebih besar dari 0,05 maka varians kelas eksperimen dan kelas kontrol adalah homogen. Tabel 2 uji homogenitas dapat dilihat sebagai berikut.

Tabel 2. Hasil Uji Homogenitas
$(-2,131<-1684)$ maka diartikan bahwa $H_{\mathrm{o}}$ ditolak dan $\mathrm{H}_{1}$ diterima.

Oleh karena $\boldsymbol{H}_{\mathbf{0}}$ ditolak maka $\boldsymbol{H}_{\boldsymbol{1}}$ yang menyatakan ada perbedaan pengaruh yang signifikan antara metode pembelajaran kooperatif tipe TSTS dan metode Ceramah terhadap hasil belajar PKn pada siswa kelas $\mathrm{X}$ SMAN 1 Pabelan semester ganjil tahun ajaran 2012/ 2013 diterima.

Perbedaan pengaruh yang signifikan antara metode pembelajaran kooperatif tipe TSTS dan metode Ceramah terhadap hasil belajar siswa pada mata pelajaran PKn ditunjukkan juga oleh rata-rata hasil belajar pada kelas eksperimen dan kelas kontrol. Pada kelas eksperimen yang diberi perlakuan menggunakan TSTS menunjukkan bahwa dari 21 siswa diperoleh nilai rata-rata kelas sebesar 80,24. Sedangkan pada kelas kontrol yang

\begin{tabular}{llllll}
\multicolumn{1}{l}{ Test of Homogeneity of Variance } \\
\hline & $\begin{array}{l}\text { Levene } \\
\text { Statistic }\end{array}$ & df1 & df2 & Sig. \\
\hline \multirow{2}{*}{ Nilipo } & Based on Mean &, 247 & 1 & 40 &, 622 \\
& Based on Median &, 294 & 1 & 40 &, 591 \\
stes & $\begin{array}{l}\text { Based on Median and with } \\
\text { adjusted df }\end{array}$ &, 294 & 1 & 39,308 &, 591 \\
& Based on trimmed mean &, 306 & 1 & 40 &, 583 \\
\hline
\end{tabular}

Analisis data dan uji hipotesis menggunakan uji Independent Sample T-Test (uji dua sampel tidak berhubungan). Uji Independent Sample T-Test ini digunakan untuk mengetahui ada tidaknya perbedaan hasil belajar siswa antara kedua kelompok kelas yaitu kelas eksperimen dan kelas kontrol. Berikut ini adalah hasil pengujian perbandingan nilai ratarata kelas yang diperlakukan dengan metode pembelajaran kooperatif tipe Two Stay Two Stray (TSTS) dan ceramah.

Dari hasi uji Independent Sampel T-Test dapat dilihat bahwa pada taraf signifikansi 5 persen, dengan df 40 ( $\mathrm{df}=42-2)$, dan t tabel diperoleh nilai sebesar 1,684 dan t hitung - 2,131. Berdasarkan uji Independent Sample T-Test diketahui nilai -t hitung <- t tabel diberi perlakuan menggunakan metode ceramah menunjukkan bahwa dari 21 siswa diperoleh nilai rata-rata sebesar 76,24.

Berdasarkan data di atas dapat dikatakan bahwa nilai rata-rata hasil belajar PKn pada kelas eksperiman lebih baik atau lebih tinggi dibandingkan kelas kontrol. Hal ini menunjukkan bahwa hasil belajar siswa yang diberi perlakuan menggunakan metode pembelajaran kooperatif tipe Two Stay Two Stray (TSTS) lebih baik dibandingkan hasil belajar siswa yang diberi perlakuan menggunakan metode ceramah yang dapat dilihat berdasarkan selisih nilai rata-rata skor postes kelas eksperimen dan kelas kontrol sebesar 4 poin.

Hasil uji hipotesis penelitian ini juga sejalan dengan pendapat Lie (2002) bahwa 
Tabel 3. Hasil perbandingan rata-rata dua variabel bebas Independent Samples Test

\begin{tabular}{|c|c|c|c|c|}
\hline & & & $\begin{array}{l}\text { Nilipostes } \\
\text { Equal variances } \\
\text { assumed }\end{array}$ & $\begin{array}{l}\text { Equal variances } \\
\text { not assumed }\end{array}$ \\
\hline \multirow{9}{*}{$\begin{array}{l}\text { Levene's Test for Equality of } \\
\text { Variances } \\
\text { t-test for Equality of Means }\end{array}$} & \multicolumn{2}{|l|}{$\mathrm{F}$} & 247 & \\
\hline & \multicolumn{2}{|l|}{ Sig. } & ,622 & \\
\hline & \multicolumn{2}{|l|}{$T$} & $-2,131$ & $-2,131$ \\
\hline & \multicolumn{2}{|l|}{ Df } & 40 & 39,072 \\
\hline & \multicolumn{2}{|l|}{ Sig. (2-tailed) } & ,039 & ,039 \\
\hline & \multicolumn{2}{|l|}{ Mean Difference } & $-4,00000$ & $-4,00000$ \\
\hline & \multicolumn{2}{|l|}{ Std. Error Difference } & 1,87694 & 1,87694 \\
\hline & \multirow{2}{*}{$\begin{array}{l}\text { 95\% Confidence Interval of } \\
\text { the Difference }\end{array}$} & Lower & $-7,79344$ & $-7,79624$ \\
\hline & & Upper &,- 20656 &,- 20376 \\
\hline
\end{tabular}

Sumber: Hasil Penelitian 2013

secara teoritis memang metode Two Stay Two Stray memberi kesempatan kepada kelompok untuk membagikan hasil dan informasi dengan kelompok lain, sehingga siswa lebih mudah memahami yang diajarkan oleh guru. Menurut Crawford dalam Hamiddin (2012), TS-TS offers a low-threat forum where students can exchange ideas and build social skills such as asking probing questions TSTS menawarkan sebuah forum dimana siswa dapat bertukar ide dan membangun keterampilan sosial seperti mengajukan pertanyaan menyelidik). Dalam kegiatan ini siswa didorong untuk menyumbangkan ide atau pendapat kepada kelompok mereka sendiri maupun kelompok lain. Pembelajaran Two Stay Two Stray memungkinkan siswa untuk saling berbagi informasi dengan kelompok-kelompok lain (Miftahul, 2011).

Dari hal tersebut menunjukkan bahwa dengan belajar kelompok atau saling mengajar (peer tutoring) dimana siswa bertukar ide dan membangun ketrampilan sosial dan saling berbagi informasi siswa dapat lebih memahami materi pelajaran yang diberikan sehingga pembelajaran kooperatif TSTS ini berpotensi meningkatkan hasil belajar siswa dibandingkan dengan pembelajaran metode ceramah.

Hasil penelitian ini sejalan dengan penelitian yang dilakukan Yusti (2011) tentang per- bedaan prestasi belajar siswa yang diajar menggunakan metode ceramah dengan siswa yang diajar menggunakan metode kooperatif Two Stay Two Stray pada mata pelajaran IPS bidang Sejarah kelas VII SMP Negeri 3 Batu. Yang menyatakan ada perbedaan dari kedua kelompok tersebut. Hasil penelitian ini menunjukkan bahwa ada perbedaan antara prestasi belajar siswa yang diajar menggunakan model Two Stay Two Stary dengan prestasi belajar dengan metode ceramah.

\section{KESIMPULAN}

Berdasarkan hasil penelitian dan pembahasan dapat disimpulkan bahwa ada perbedaan pengaruh yang signifikan antara penggunaan metode pembelajaran kooperatif tipe TSTS (Two Stay Two Stray) dan metode Ceramah terhadap hasil belajar pada mata pelajaran Pknsiswa kelas X SMA Negeri 1 Pabelan Kecamatan Pabelan Kabupaten Semarang semester ganjil tahun ajaran 2012/2013. Hasil belajar yang menggunakan TSTS lebih baik dibandingkan dengan metode Ceramah.

\section{SARAN}

Guru diharapkan dapat menggunakan metode pembelajaran kooperatif TSTS untuk meningkatkan hasil belajar siswa pada mata pelajaran yang lain. 


\section{DAFTAR PUSTAKA}

Anita, Lie. 2002. Cooperatif Learning: Mempraktikkan Cooperatif Learning di Ruang-Ruang Kelas. Jakarta: Grasindo.

Haning, Vianata. Indonesian Journal of History Education; Pengaruh Model Pembelajaran Question Student Have Terhadap Hasil Belajar IPS Sejarah Siswa. 2012. Semarang: Fakultas Ilmu Sosial, Universitas Negeri Semarang.

Miftahul, Huda. 2011. Cooperative Learning. Yogyakarta: Pustaka Pelajar.

Made, Wena. 2011. Strategi Pembelajaran Inovatif Kontemporer. Jakarta: Bumi Aksara.

Siti Aminah, http://psb-psma.org/content/blog/ pembelajaran kooperatif. Diakses tanggal 21 November 2011 jam 10.15 am.

Slameto. 2010. Belajar dan Faktor-Faktor Yang Mempengaruhinya. Jakarta: Rineka Cipta .

Sudjana, Nana. 2010. Penilaian Hasil Belajar Mengajar. Bandung: Remaja Rosdakarya.
Widi Rahardja. 2002. Sekitar Strategi Belajar Mengajar dan Ketrampilan Mengajar. Salatiga: FKIP UKSW.

Yusnita, Winda. 2012. http//digilib.ac.id/ UNIMED-undergraduate-0122148/ 22627

Yusritawati.2009.http://furahasekai. wordpress.com/2011/09/07/ pembelajaran kooperatif tipe Two Stay Two Stray. Diakses pada tanggal 5 November 2012 jam 2:15pm

Yusti, Palupi Megasari. 2011. Perbedaan Prestasi Belajar Siswa yang Diajar Menggunakan Metode Pembelajaran Ceramah dengan Siswa yang Diajar dengan Menggunakan Metode Kooperatif Model Two Stay Two Stray pada mata pelajaran IPS Bidang Sejarah kelas VII SMP Negeri 3 Batu. Jurusan Sejarah, Fakultas Ilmu Sosial, Universitas Negeri Malang. 